\title{
Assessing School Principals' Perceptions of School Effectiveness in the Palestinian Schools
}

\author{
Aysha Mohammad Qasem Abd-Rabo*, Sherine Adnan Ismail Hashaikeh \\ Faculty of Educational Sciences and Teachers Training, An-Najah National University, Palestine
}

Received July 31, 2020; Revised September 3, 2020; Accepted October 19, 2020

\section{Cite This Paper in the following Citation Styles}

(a): [1] Aysha Mohammad Qasem Abd-Rabo, Sherine Adnan Ismail Hashaikeh, "Assessing School Principals' Perceptions of School Effectiveness in the Palestinian Schools," Universal Journal of Educational Research, Vol. 8, No. 11, pp. 5536 - 5546, 2020. DOI: 10.13189/ujer.2020.081157.

(b): Aysha Mohammad Qasem Abd-Rabo, Sherine Adnan Ismail Hashaikeh (2020). Assessing School Principals' Perceptions of School Effectiveness in the Palestinian Schools. Universal Journal of Educational Research, 8(11), 5536 5546. DOI: 10.13189/ujer.2020.081157.

Copyright $\odot 2020$ by authors, all rights reserved. Authors agree that this article remains permanently open access under the terms of the Creative Commons Attribution License 4.0 International License

\begin{abstract}
School effectiveness is a multifaceted term; one of its meanings refers to the level of goal attainment of a school. When researchers explore the literature that relates to school effectiveness, we noticed that much of this literature is theoretical. This situation has led us to design a Likert type school effectiveness scale to define the qualities of effective schools, by investigating the exploratory factor analysis results of school effectiveness scale. The present questionnaire examines principals' perceptions of six school effectiveness factors: the effectiveness of school climate, school administration effectiveness, the effectiveness of the teacher, the effectiveness of the relationship with the local community, the effectiveness of educational practices, the student's having a sense of belonging to the surrounding environment. This questionnaire is factorable and explains $62.594 \%$ of the variance of a more general school effectiveness score. The questionnaire was distributed to 243 school principals, and the collected data was analyzed by computing a one sample t-test to assess participants' scores in relation to the six school effectiveness factors. The results indicated that scores are high 'mostly'.
\end{abstract}

Keywords School Effectiveness, Palestinian Schools, Questionnaire

\section{Introduction}

Education in general, and schools in particular, aim to provide knowledge, skills and behaviors that young people need to be active and productive in society. Schools are supposed to contribute to the development of society; and this requires that schools be effective to achieve the desired goals in the present and in the future. Education in school related to how to achieve educational objectives and school is the most important educational organization created to develop quality of education in line with the sustainable development goals. As an organization (Karabatak et al, 2018), schools have a number of goals and levels of effectiveness, Researchers in the field of educational effectiveness have the problem of determining effectiveness criteria. It should be something other than the characteristics and advantages of education in the educational system, in schools and in the classroom (Panigrahi, 2014). The principal's ability plays an important role in the development of schools and educational institutions (Kempa et al, 2017). Principals must be able to manage educational resources in schools that include: teachers, educational facilities, infrastructure, curricula, and cooperation opportunities with educational institutions. The good management of all such elements leads to the effective leadership that helps achieve the school's vision and mission. School principals play an inevitable role in supporting the school, staff and students' performance. Therefore, their role is very vital in enhancing school effectiveness and developing education in any country (AlShehhi \& Alzouebi, 2020).

School effectiveness is the ability of the principal to improve the learning environment in order to promote 
achievement of educational goals and objectives (Chiedozie et Victor, 2016),. To measure the effectiveness of the school, there must be adequate inputs in terms of good educational leadership practices, effective management practices and enabling a teaching and learning environment leading to academic achievement for students.

Schools are important entities in modern societies (Nor, 2014) because they are social institutions that many people care about, including decision-makers in society. Moreover, parents tend to send their children to schools with good reputation and choose schools that have a good achievement record Thus, there is an increasing interest in making schools more effective and achieving high expectations for everyone in society. When a school is efficient, it attracts more students and gains the confidence of community.

Despite widespread practice and implementation of many initiatives to enhance the effectiveness of the school (Botha, 2010), there is no clear or uniformly accepted set of guidelines, assumptions, or standards in relation to evaluating school effectiveness. Discussions and studies on what constitutes school effectiveness are continuing (Özgenel, 2020). In addition, it is desirable or even necessary to enact the school effectiveness. In addition, such school effectiveness needs to be assessed to ensure that they are appropriately implemented. One way to assess school effectiveness and their relation with other variables is through quantitative methods, with a questionnaire as the main tool. The present research attempts to achieve this and presents a questionnaire to assess six school effectiveness fields: the effectiveness of the school climate, school administration effectiveness, the effectiveness of the teacher, the effectiveness of the relationship with the local community, the effectiveness of educational practices, the effectiveness of educational practices and the student's sense of belonging to the surrounding environment.

\section{Research Goals and Rationale}

There are different models of school effectiveness that aimed at explaining and determining what makes school effective (Burušić et al., 2016). Most current school effectiveness research focuses on teaching and learning in relation to academic achievement. We still don't know much about what the focus should be when assessing school effectiveness (Dijkstra et al, 2017). Şengür et. al (2018) argues that the literature exploring many factors that affect school effectiveness and research continues until now. Educational researchers have offered various questionnaires to assess school effectiveness in order to explore conceptual models derived from proposed networks of variables. For instance, Özgenel (2020) used "The School Effectiveness Index" together with the Organizational Description Climate Scale for Elementary
Schools (OCDQ-RE]) in order to determine if school climate affects school effectiveness. A questionnaire was developed by Al-Barami \& Tanash (2010) which consisted of 100 items, distributed over seven areas: the principals' behavior, the teachers' behavior, students' behavior, school climate, supervision behavior, students' achievement, and school relationship with local community in order to investigate the effectiveness of the basic public schools. Çakir \&Kesme (2018) developed the Effective School Scale to determine the effectiveness levels of schools according to teachers' opinions, and to determine the level of Effective Schools in terms of the number of EU Projects (Erasmus +, eTwinning) carried out by official Vocational and Technical Anatolian High Schools in the central district of Giresun province, in terms of manager, teacher, student, school culture, environment school program and education process, school environment, and parent dimensions.

The present research offers one step towards providing such empirical research. In that, it offers a questionnaire to assess principals' perceptions of school effectiveness relating to six components: the school administration, the teacher, students, school climate, educational practices, relationship with the local community. It does so in the context of the Palestinian school.

\section{Literature Review}

School effectiveness is used as an umbrella term for the approach to evaluating schools (Gray, 2016). School effectiveness evaluation is a complex process due to its various dimensions (Singh, 2020). School effectiveness research has been increasingly criticized for its excessively narrow focus on the measurement of school knowledge. (Burušić et al., 2016) demonstrated that the future challenge of educational effectiveness research is to develop valid and reliable measures of different educational outcomes, in addition to those narrowly cognitive. Botha (2010) argued that there should be two objectives for these studies: the first one is to identify the factors that can characterize effective school, and the second is to determine differences between these schools.

Beshara (2017) stated that there are various approaches in defining the concept of school effectiveness which can be expressed as the degree to which school's educational, organizational, and administrative goals are achieved (Özgenel, 2020). On the other hand, the effectiveness of school could be defined as an open social system, which is closely related to all of the input process-output components as stated by (Hoy \& Miskel, 2012).

Uline et. Al (1998) explored some dimensions of the school effectiveness: the instrumental functions and the expressive functions which help to make the school structure multi-faceted and easy to manage. The modern concept of school effectiveness is based, in essence, on 
concern for the various stakeholders to education, such as parents, teachers, students, administrators, and the rest of the community groups related to the school (OECD, 2018; Olorunsola and Belo, 2018; Burušić et al, 2016).

For example, principals focus on measuring the aspects of school bureaucracy as an input to measuring effectiveness, such as maintaining order and adhering to instructions and laws, engaging teachers to build a school culture for continuous improvement, and controlling different school activities to maintain focus on educational tasks and to ensure that teachers work and fulfill their responsibilities in accordance with the school's educational goals (Özgenel, 2020, Gray,2016). As for the teachers, they focus on the teaching methods, processes and activities that they practice (European Commission, 2019), On the other hand, students, parents and the local community focus on school productivity by measuring students 'achievement, their academic level and the value system they carry (OECD, 2016).

A school with shared and effective visions and goals (Beshara, 2017), effective teaching and learning, great cooperation between principal and teacher and among the teachers themselves, a positive learning environment, effective evaluation (Özgenel,2020). To measure the effectiveness of a school, adequate inputs must be made in terms of good educational leadership practices, effective management practices, and enabling a teaching and learning environment that leads to student academic achievement (Işik, 2020; Preston et al ,2017).

Every school is single and unique although the same basic functions are the same. An indicator for school quality is that it is "effective" (Baştepe, 2002). It is not easy to determine the effectiveness; students' academic success is often taken into account through politics makers and researchers as an indicator of the effectiveness of the school (Işik, 2020).

Bottery (2004) stated that standardized student tests and rigid curriculum standards are preferred to ensure school performance, in the western world. Unfortunately it applies also to Palestine.

The effectiveness of the school is explained by several models that are developed by using different predictions perspectives. While school effectiveness is determined by the degree to which goals are set according to a particular model, it is explained as a satisfaction with education stakeholders such as teachers, students, administrators, and parents in another model (Balci, 2013). To say that the organization is effective (Özgenel, 2020), the empirical evidence of effectiveness is required.

\section{School performance criteria}

What influences school performance?

Education experts focus on the relationships between education outcomes and resources allocation, how school system is governed and organized, and learning environment in the school (European Commission, 2019; Preston et al, 2017).

Models of school performance often take into account four components: inputs, process, outputs and the context. These components include many levels of the school organization, management, the teacher and / or classroom level, the level of individual student performance and background (Scheerens \& Creemers, 1989). Since schools are complex structures, it seems difficult to imagine specific standards for school performance (Bishara, 2017).

The effectiveness of the school is directly proportional to the objectives of the school. However, it is difficult to determine the effectiveness of schools due to difficulties related to measuring the quality of school results. There are very important factors in terms of school effectiveness such as administrative function, leadership behaviors, morale, the school climate, level of confidence, cultural climate, parent participation, community support, teacher competency, teacher loyalty, commitment, and job satisfaction (OECD, 2018; Uline el al, 1998; European Commission, 2019), and what happens in classroom is influenced by the decisions and context made at higher levels in school administrations (Olorunsola and Belo,2018).

Internationally, researchers have conducted several studies in order to reveal the factors that are taken into consideration when studying school effectiveness. Panigrahi (2014) investigated the relationship of school effectiveness with regard to the classroom teaching at primary level of education. The study revealed that there is no simple combination of factors which can produce effective school. The study has, however, revealed that the school effectiveness has emerged as related to classroom teaching. Chiedozie et Victor (2017) confirmed the principals' application of instructional leadership practices for secondary school effectiveness in Oyo State. According to the findings, it was recommended that school principals should regularly monitor teachers' instructional delivery and their level of compliance to school schedule in order to enhance teachers' commitment to teaching and it should be the morale of teachers in this school is high. Olorunsola and Belo (2018) examined the administrative challenges and principals' managerial effectiveness in Ogun State secondary schools. The findings revealed that finance is the best predictor of principals' managerial effectiveness while the physical facility is the least predictor. It was concluded that administrative challenges are critical variables of principals' managerial effectiveness; therefore, it was recommended that the government should give out its supportive arms by releasing grants to the schools. Preston et al (2017) demonstrated eight essential components of effective high schools emerging from a review of effective schools and high school reform literature, and provided a framework for how these components are implemented and integrated. These components are: learning-centered leadership, rigorous and aligned curriculum, quality 
instruction, systemic use of data, personalized learning connections, culture of learning and professional behavior, systemic performance accountability, and connections to external communitie . Al Mekhlaf \& Osman (2019) examined the impact of a holistic school improvement model on overall school effectiveness., They used a quasi-experimental design to verify the impact of the overall school improvement model on strengthening the school effectiveness in Oman. The sample consisted of 16 classrooms from 8 schools (4 experimental and 4 control groups), with a total of 2,378 students. The experimental schools were exposed to a wide range of school improvement activities for a period of four years. The findings of the study revealed significant differences in school performance over the four years between the experimental schools group and the control schools in favor of the experimental group. Alanoğlu1 \& Demirtaş (2016) determined the relationships between the organizational learning levels of high schools, organizational citizenship behavior of managers and teachers, and their effective school characteristics based on opinions of the managers and teachers serving at high schools in Diyarbakir city in Turkey, during 2013-2014 educational year. The findings revealed that the perception of managers and teachers on learning school and effective school characteristic was at average level whereas their perception on organizational citizenship behavior was at high level. Moreover, organizational citizenship behavior of managers and teachers are predictors of effective school characteristic.

\section{Objectives of the Study}

This study provides the educators and researchers with a conceptual basis for defining school effectiveness, and describes what the school effectiveness are expected to "work" in education, by designing a Likert type school effectiveness scale to investigate principals attitudes towards school effectiveness, and by investigating the exploratory factor analysis results of school effectiveness scale. The questionnaire can be used as a guideline in providing answers on what can be done in order to increase educational quality, and educators learn about the methods in which educational policies may enhance school effectiveness, which contributes to achieving educational goals.

\section{Methodology}

\section{Research context and sample}

The study population (n. 745) consisted of all the basic public school principals in the provinces of the northern West Bank (Tulkarem, Jenin, Qalqiliya, Salfit, Qabatiya, Tubas, Nablus, and south of Nablus,), in the academic year (2019 - 2020). A sample size of school principals (n. 243) participated in the research at a rate of $(32.6 \%)$ of the population of the study. The study sample was selected by taking a random stratified sample.

\section{Tool design}

The questionnaire was developed based on review of the literature and previous studies such as: Çakir \& Kesme (2018) (OECD, 2018), this providing a background and rationale for the study. The first section of the questionnaire included demographic variables, which formed the variables:

1. Gender: male or female,

2. Educational qualification: diploma, bachelor, master or higher,

3. Years of management experience: less than 5 years, from 5 to 10 years, more than 10 years

4. The principal's place of residence: village, city

The second section included 38 effectiveness items which were distributed in six school effectiveness factors: the effectiveness of the school climate, school administration effectiveness, the effectiveness of the teacher, the effectiveness of the relationship with the local community, the effectiveness of educational practices, the student's having a sense of belonging to the surrounding environment.

The distribution of principals according to gender and level of school effectiveness is described in Table 1.

Table 1. The distribution of the sample according to gender and level of school effectiveness

\begin{tabular}{|c|c|c|c|c|c|c|c|}
\hline \multicolumn{2}{|c|}{} & \multicolumn{9}{c|}{ level in school effectiveness } \\
\cline { 3 - 9 } & & never & rarely & sometimes & mostly & always & total \\
\hline \multirow{3}{*}{ gender } & Male & 1 & 1 & 24 & 77 & 21 & 124 \\
\cline { 2 - 9 } & female & 2 & 5 & 22 & 73 & 17 & 119 \\
\hline \multirow{2}{*}{ total } & & 3 & 6 & 46 & 150 & 38 & 243 \\
\hline
\end{tabular}


Table 2. Means, standard deviations and skewness of the questionnaire items $(\mathrm{N}=243)$

\begin{tabular}{|c|c|c|c|}
\hline item & M & $\mathrm{SD}$ & Skew \\
\hline Students respect the regulations prevailing in the school & 4.07 & 0.62 & -0.45 \\
\hline Students have the ability to feel the aesthetic aspects around them & 3.80 & 0.65 & -0.59 \\
\hline Students interact with others in a positive way & 3.87 & 0.61 & -0.70 \\
\hline The school encourages students to work together & 4.28 & 0.62 & 0.80 \\
\hline The school climate helps students to be creative & 3.87 & 0.68 & -0.93 \\
\hline Cooperation prevails among members of the school community & 4.16 & 0.67 & -0.94 \\
\hline The school has a safe environment & 4.24 & 0.73 & -0.97 \\
\hline The school climate contributes to developing different aspects of students' personality & 4.04 & 0.69 & -0.72 \\
\hline The school organizes various learning activities in an interactive atmosphere & 3.99 & 0.66 & -0.76 \\
\hline The principal works to educate students about the importance of school activity & 4.32 & 0.58 & -0.33 \\
\hline The principal creates the school environment to carry out the school activity & 4.37 & 0.57 & -0.36 \\
\hline The principal provides the necessary capabilities to carry out the school activity & 4.37 & 0.55 & -0.09 \\
\hline The principal works to activate the relationship between the school and the local community & 4.46 & 0.60 & -1.09 \\
\hline The principal tracks the professional needs of teachers & 4.44 & 0.61 & -0.80 \\
\hline The manager uses educational facilities to serve the educational performance & 4.44 & 0.60 & -0.79 \\
\hline The principal provides material incentives for students participating in the school activity & 4.21 & 0.78 & -1.17 \\
\hline The teacher varies in teaching methods & 3.91 & 0.66 & -0.42 \\
\hline The teacher uses the computer and its applications in the learning process & 3.85 & 0.73 & -0.13 \\
\hline The teacher prepares different teaching aids & 3.95 & 0.71 & -0.21 \\
\hline The teacher motivates students to learn & 4.10 & 0.58 & -0.02 \\
\hline The teacher uses modern educational techniques & 3.90 & 0.69 & -0.08 \\
\hline The teacher is interested in gifted students & 3.95 & 0.71 & -0.28 \\
\hline The teacher uses different teaching methods & 3.91 & 0.66 & -0.06 \\
\hline The local community participates in the various activities of the school & 3.81 & 0.79 & -0.40 \\
\hline The community provides support for the school & 3.70 & 0.91 & -0.62 \\
\hline The school contributes to voluntary activities that serve the local community & 3.71 & 0.76 & $0.31-$ \\
\hline The local community uses the school facilities on its various occasions & 3.78 & 0.63 & -0.60 \\
\hline The school takes suggestions from the Parents' Council & 3.92 & 0.60 & -0.54 \\
\hline The teacher uses enrichment activities in each class & 3.81 & 0.79 & -0.40 \\
\hline The prevailing method of teaching in the school is conversational & 3.70 & 0.91 & -0.62 \\
\hline School practices enhance self-learning & 3.71 & 0.76 & $0.31-$ \\
\hline The teacher knows the main principles for planning school activities & 3.24 & 1.07 & -0.53 \\
\hline The method of teaching is based on scientific foundations & 3.88 & 0.73 & -0.93 \\
\hline The school contributes to introducing students to archeological sites & 3.77 & 0.71 & -0.59 \\
\hline The school links the learning process to the needs of society & 3.56 & 0.74 & -0.69 \\
\hline The school contributes to adult literacy programs & 3.51 & 1.16 & -0.24 \\
\hline The school works to educate students about forest wealth & 3.27 & 0.92 & -0.52 \\
\hline The school works to acquaint students with water resources & 3.47 & 0.84 & -0.56 \\
\hline
\end{tabular}

The descriptive statistics (means, standard deviations and skewness) of the questionnaire items are given in Table 2 .

\section{Analysis method of the level of school effectiveness scores in the Palestinian schools}

To calculate effectiveness mean scores for the principals participating in the research, the researchers computed first grouped frequency distributions (daher, 2019). Then they compared the resulting effectiveness mean scores with a 'mostly effectiveness score' and a 'sometimes effectiveness score'. We computed the "sometimes effectiveness score ", the range is $(5-1=4)$ then they divide 4 by 5 (where number one is the lowest score of any item, and number five is the highest $).(4 \div 5=0.80)$ which was used to find intervals on a scale presented in Figure 1. We considered point (1.8) to be a 'rarely effectiveness score', (2.6) to be a 'sometimes effectiveness score' and (3.4) to be a 'mostly effectiveness score' on this scale. Thus, the scores between (1) and (1.8) were considered 'never effectiveness scores', the scores between (1.8) and 
(2.6) 'rarely effectiveness scores', the scores between (2.6) and (3.4) 'sometimes effectiveness scores', the scores between (3.4) and (4.2) 'mostly effectiveness scores', and the scores between (4.2) and (5) 'always effectiveness scores'.

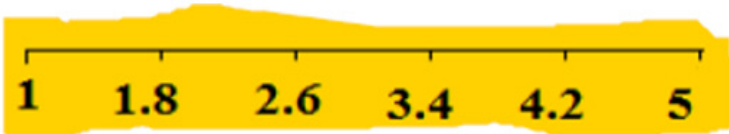

Figure 1. Intervals related to the effectiveness scores of any item (daher, 2019)

To compare the principals mean scores with the 'sometimes effectiveness score' and the 'mostly effectiveness score' we used a one-sample t-test and compared with the appropriate effectiveness value.

\section{The Results}

At first, the factorability of the 38 effectiveness items was examined. The data was sifted for factorability using several well recognized criteria. Initially, all the items are correlated at least .4 with at least one other item, indicating reasonable factorability, and $\mathrm{KMO}$ value measure of sampling adequacy was found .895 , above the commonly recommended value of .6 , and Bartlett's test of sphericity result was significant $\left(\chi^{2}(703)=5187.354, \mathrm{p}<.001\right)$. The diagonals of the anti-image correlation matrix were also all over .5 , the communalities were all above .45 , further confirming that each item shared some common variance with other items. Given these overall indicators, factor analysis was deemed to be suitable with all 38 items.

Factor loadings based on rotated principal components analysis with varimax rotation for 38 items from the above scale $(\mathrm{N}=243)$ are presented in table 3 , varimax rotation method was used to give a better picture of factors in this analysis.

The principal component analysis (PCA) was used to bring out strong patterns in a dataset and Initial eigenvalues indicated that the first six factors explained $12.28 \%, 3.09 \%$, $2.43 \%, 1.92 \%, 1.56 \%$ and $1.38 \%$ of the variance respectively.

Our adoption of the sixth-factor model depended on the results of the principal factor analysis, including the total-variance-explained table and the scree plot (see Figure 2 below). According to the solution, the six factors explained $62.594 \%$ ) of the variance in the effectiveness scores. and this percentage is considered acceptable in social science Studies (Akay\&Aypay,2016).

\section{Scree Plot}

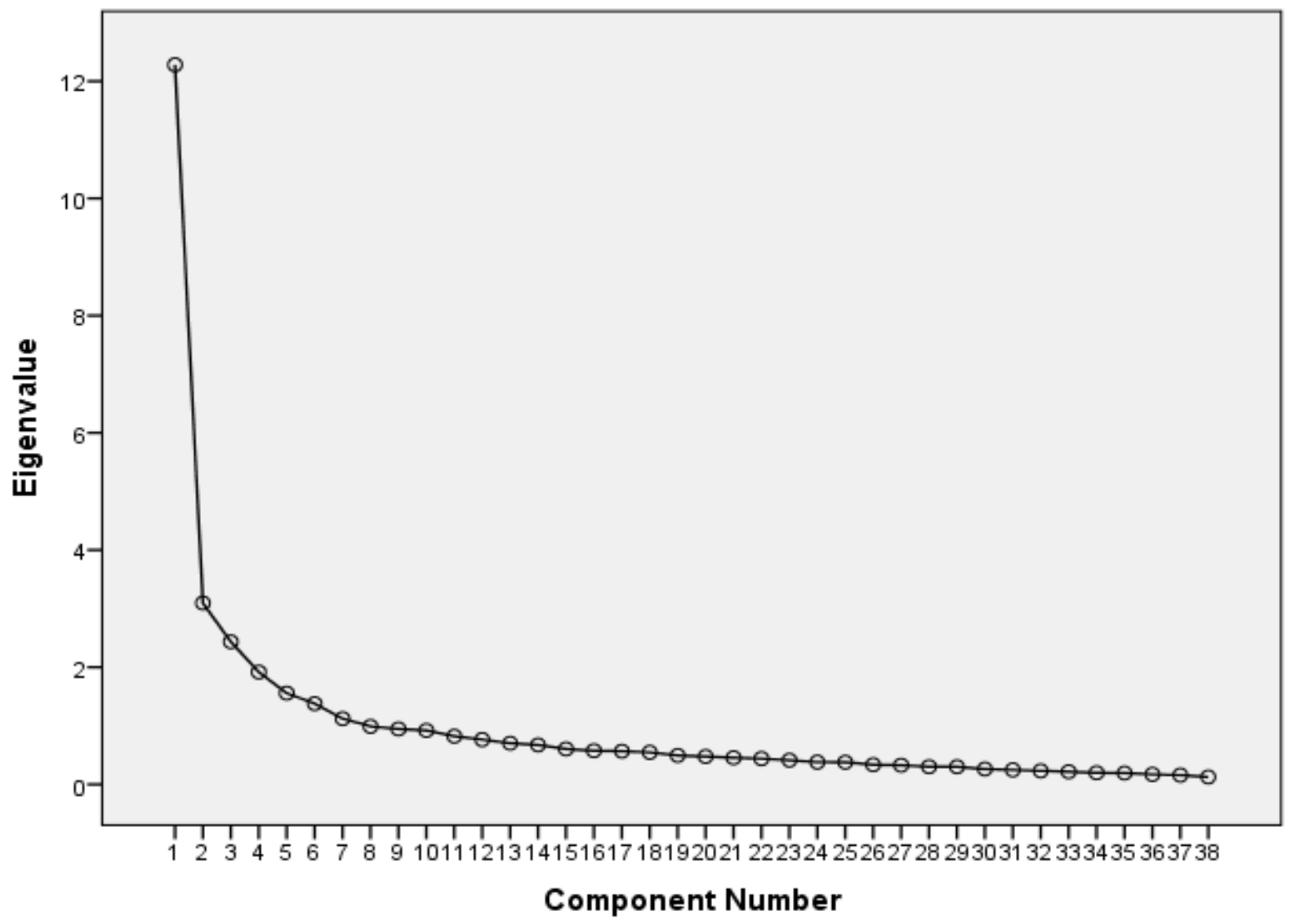

Figure 2. Scree Plot of the items factorization 
Table 3. Factor loadings based on varimax -rotated principal components analysis $(\mathrm{N}=243), 1=$ The effectiveness of the school climate, $2=$ School administration effectiveness, $3=$ The effectiveness of the teacher, $4=$ The effectiveness of the relationship with the local community, $5=$ The effectiveness of educational practices , $6=$ The student's have a sense of belonging to the surrounding environment.

\begin{tabular}{|c|c|c|c|c|c|c|}
\hline \multirow{2}{*}{ item } & \multicolumn{6}{|c|}{ Component } \\
\hline & 1 & 2 & 3 & 4 & 5 & 6 \\
\hline Students respect the regulations prevailing in the school & .42 & & & & & \\
\hline Students have the ability to feel the aesthetic aspects around them & .56 & & & & & \\
\hline Students interact with others in a positive way & .68 & & & & & \\
\hline The school encourages students to work together & .63 & & & & & \\
\hline The school climate helps students to be creative & .66 & & & & & \\
\hline Cooperation prevails among members of the school community & .79 & & & & & \\
\hline The school has a safe environment & .76 & & & & & \\
\hline $\begin{array}{l}\text { The school climate contributes to developing different aspects of students' } \\
\text { personality }\end{array}$ & .72 & & & & & \\
\hline The school organizes various learning activities in an interactive atmosphere & .64 & & & & & \\
\hline The principal works to educate students about the importance of school activity & & .69 & & & & \\
\hline The principal creates the school environment to carry out the school activity & & .81 & & & & \\
\hline The principal provides the necessary capabilities to carry out the school activity & & .71 & & & & \\
\hline $\begin{array}{l}\text { The principal works to activate the relationship between the school and the local } \\
\text { community }\end{array}$ & & .67 & & & & \\
\hline The principal tracks the professional needs of teachers & & .72 & & & & \\
\hline The manager uses educational facilities to serve the educational performance & & .74 & & & & \\
\hline $\begin{array}{l}\text { The principal provides material incentives for students participating in the school } \\
\text { activity }\end{array}$ & & .55 & & & & \\
\hline The teacher varies in teaching methods & & & .62 & & & \\
\hline The teacher uses the computer and its applications in the learning process & & & .72 & & & \\
\hline The teacher prepares different teaching aids & & & .78 & & & \\
\hline The teacher motivates students to learn & & & .70 & & & \\
\hline The teacher uses modern educational techniques & & & .72 & & & \\
\hline The teacher is interested in gifted students & & & .53 & & & \\
\hline The teacher uses different teaching methods & & & .47 & & & \\
\hline The local community participates in the various activities of the school & & & & .74 & & \\
\hline The community provides support for the school & & & & .79 & & \\
\hline The school contributes to voluntary activities that serve the local community & & & & .65 & & \\
\hline The local community uses the school facilities on its various occasions & & & & .62 & & \\
\hline The school takes suggestions from the Parents' Council & & & & .53 & & \\
\hline The teacher uses enrichment activities in each class & & & & & .50 & \\
\hline The prevailing method of teaching in the school is conversational & & & & & .72 & \\
\hline School practices enhance self-learning & & & & & .72 & \\
\hline The teacher knows the main principles for planning school activities & & & & & .55 & \\
\hline The method of teaching is based on scientific foundations & & & & & .53 & \\
\hline The school contributes to introducing students to archeological sites & & & & & & .66 \\
\hline The school links the learning process to the needs of society & & & & & & .59 \\
\hline The school contributes to adult literacy programs & & & & & & .52 \\
\hline The school works to educate students about forest wealth & & & & & & .84 \\
\hline The school works to acquaint students with water resources & & & & & & .68 \\
\hline
\end{tabular}




\section{Validity and reliability analysis}

Validity and reliability analyses were performed for the six factors. To ensure validity, the first-version of the questionnaire has been examined by (5) experts working in educational sciences institute, to analyze it and thus verify its validity for data collection. Thus, the number of items has been reduced, and the necessary corrections were made to the scale, which gave the present 38-item, and have been designed in the 5-point Likert type scale. To ensure reliability, Cronbach's Alpha was found for each of the six effectiveness factors. This computation gave .90 for the effectiveness of the school climate, .85 for school administration effectiveness, .86 .5 for the effectiveness of the teacher, .80 .8 for the effectiveness of the relationship with the local community, .82 for the effectiveness of educational practices and .74 .8 for the student's sense of belonging to the surrounding environment. These reliability results indicate good reliability for the all constructs. because these reliabilities are around .80 (Akay\&Aypay,2016). The Cronbach Alpha computation for the whole questionnaire is .93 which indicates high reliability.

\section{Level of school effectiveness scores in the Palestinian schools}

To assess the level of school effectiveness scores in the Palestinian schools, we computed means and standard deviations for the six factors: the effectiveness of the school climate, school administration effectiveness, the effectiveness of the teacher, the effectiveness of the relationship with the local community, the effectiveness of educational practices and the student's sense of belonging to the surrounding environment.

We also conducted a one-sample $t$ test to assess the statistical significance of the variation of each factor with a rarely, sometimes and mostly level of school effectiveness (see Table 4).

It was noticed that the scores in six factors did not show a normal distribution, but we used t-test, which is a parametric test because normality actually does not matter at all when sample size is relatively large (Yang $\mathrm{K}$, et al ,2019).

Table 4. Level of school effectiveness scores in the Palestinian schools $(\mathrm{N}=243), * * \mathrm{p}<.000$

\begin{tabular}{|c|c|c|c|c|}
\hline \multicolumn{2}{|c|}{} & \multicolumn{3}{|c|}{ T value } \\
\hline component & $\mathrm{M}(\mathrm{SD})$ & rarely & sometimes & Mostly \\
\hline 1 & $4.03(0.49)$ & $70.43^{* *}$ & $45.23^{* *}$ & $20.05^{* *}$ \\
\hline 2 & $4.37(0.45)$ & $88.94^{* *}$ & $61.29^{* *}$ & $33.65^{* *}$ \\
\hline 3 & $3.94(0.51)$ & $65.75^{* *}$ & $41.15^{* *}$ & $16.55^{* *}$ \\
\hline 4 & $3.67(0.65)$ & $44.85^{* *}$ & $25.65^{* *}$ & $6.46^{* *}$ \\
\hline 5 & $3.73(0.51)$ & $58.58^{* *}$ & $34.31^{* *}$ & $10.04^{* *}$ \\
\hline 6 & $3.32(0.63)$ & $37.47^{* *}$ & $17.71^{* *}$ & -2.05 \\
\hline
\end{tabular}

\section{Discussion and Conclusions}

Because most current school effectiveness research focuses on teaching and learning in relation to academic achievement, the literature explores many factors that affect school effectiveness, in addition to academic achievement. Empirical research regarding school effectiveness in schools still needs more attention. One way to improve such empirical research is to develop research quantitative tools, such as questionnaires, to assess the level of school effectiveness in the Palestinian schools (daher, 2019). The present research offers a questionnaire that assesses six school effectiveness factors: the effectiveness of the school climate, school administration effectiveness, the effectiveness of the teacher, the effectiveness of the relationship with the local community, the effectiveness of educational practices, and the having a sense of belonging to the surrounding environment. These six factors explain $62.594 \%$ of the variance in the overall school effectiveness score across our sample.

A questionnaire suggested in the present study may help researchers study the level of school effectiveness scores in schools. The researcher used the suggested questionnaire to examine the school effectiveness in the basic public Palestinian schools from the principals perspective, The results indicate that the level of school effectiveness in the Palestinian schools is high (mostly) in all factors except the factor (the student's sense of belonging to the surrounding environment). There may be various reasons that explain this level of school effectiveness, effective leadership practices improve school organization, teaching, and student achievement outcomes. The principal realizes the importance of school development and success by seeking to provide a suitable school environment for effective learning to take place. The principal is involved in planning, contributes to teacher training, and works to solve problems faced the teachers and students (Tosh \& Doss, 2019).

The school effectiveness clearly depends on the effectiveness of the school climate, school administration effectiveness, the effectiveness of the teacher, the effectiveness of the relationship with the local community, the effectiveness of educational practices. On the basis of the findings, it is essential to realize that when the teacher varies in teaching methods and motivates students to learn, and when cooperation prevails among members of the school community, when there is healthy student-teacher interaction, effective teaching and effective evaluation process, all of these factors constitute parameters for effective learning which contribute to high effectiveness in schools.

In addition, the effectiveness of students is attributed to interest of the Ministry of Education and their adoption of policies and regulations that contribute to involving students in the learning process in an effective manner. As 
for the effectiveness of the school climate, it is attributed to the school systems that make the school environment safe. It is dominated by cooperation between the principal, teacher and student. This encourages students to engage in the school environment in an effective manner.

The present study indicates the need to improve the level of the student's having a sense of belonging to the surrounding environment in the Palestinian schools. This could be done by different means. First, by linking the learning process to the needs of society. Second, by promoting learning and social development work with individuals and groups in their communities using a range of formal and informal methods (Akay\& Aypay,2016).
Researchers recommend that school performance criteria should be developed instead of defining it in terms of outcomes, by designing school performance criteria that emphasize skills of social value and the contribution of schools to growth in student achievement from the contributions of family and community.

However, this study has some limitations. The scale was used only to evaluate school effectiveness from the principals perspective. In order to draw a full picture of school effectiveness, the same scale could be conducted with teachers. This implementation could create more results in terms of the reliability and validity of the scale.

\section{Appendix}

\begin{tabular}{|c|c|}
\hline factor & item \\
\hline \multirow{9}{*}{ The effectiveness of the school climate } & Students respect the regulations prevailing in the school \\
\hline & Students have the ability to feel the aesthetic aspects around them \\
\hline & Students interact with others in a positive way \\
\hline & The school encourages students to work together \\
\hline & The school climate helps students to be creative \\
\hline & Cooperation prevails among members of the school community \\
\hline & The school has a safe environment \\
\hline & $\begin{array}{l}\text { The school climate contributes to developing different aspects of students' } \\
\text { personality }\end{array}$ \\
\hline & The school organizes various learning activities in an interactive atmosphere \\
\hline \multirow{7}{*}{ School administration effectiveness } & The principal works to educate students about the importance of school activity \\
\hline & The principal creates the school environment to carry out the school activity \\
\hline & The principal provides the necessary capabilities to carry out the school activity \\
\hline & $\begin{array}{l}\text { The principal works to activate the relationship between the school and the local } \\
\text { community }\end{array}$ \\
\hline & The principal tracks the professional needs of teachers \\
\hline & The manager uses educational facilities to serve the educational performance \\
\hline & $\begin{array}{l}\text { The principal provides material incentives for students participating in the } \\
\text { school activity }\end{array}$ \\
\hline \multirow{7}{*}{ The effectiveness of the teacher } & The teacher varies in teaching methods \\
\hline & The teacher uses the computer and its applications in the learning process \\
\hline & The teacher prepares different teaching aids \\
\hline & The teacher motivates students to learn \\
\hline & The teacher uses modern educational techniques \\
\hline & The teacher is interested in gifted students \\
\hline & The teacher uses different teaching methods \\
\hline \multirow{5}{*}{$\begin{array}{l}\text { The effectiveness of the relationship with the local } \\
\text { community }\end{array}$} & The local community participates in the various activities of the school \\
\hline & The community provides support for the school \\
\hline & The school contributes to voluntary activities that serve the local community \\
\hline & The local community uses the school facilities on its various occasions \\
\hline & The school takes suggestions from the Parents' Council \\
\hline \multirow{5}{*}{ The effectiveness of educational practices } & The teacher uses enrichment activities in each class \\
\hline & The prevailing method of teaching in the school is conversational \\
\hline & School practices enhance self-learning \\
\hline & The teacher knows the main principles for planning school activities \\
\hline & The method of teaching is based on scientific foundations \\
\hline \multirow{5}{*}{$\begin{array}{l}\text { the student's have a sense of belonging to the } \\
\text { surrounding environment }\end{array}$} & The school contributes to introducing students to archeological sites \\
\hline & The school links the learning process to the needs of society \\
\hline & The school contributes to adult literacy programs \\
\hline & The school works to educate students about forest wealth \\
\hline & The school works to acquaint students with water resources \\
\hline
\end{tabular}




\section{REFERENCES}

[1] A.M. Al Mekhlafi, M. E Tahir Osman. The effect of a holistic school improvement model in enhancing school effectiveness in Oman. Malaysian Journal of Learning and Instruction, Vol. 16, No.2, 187-200, 2019.

[2] A. Balci. Etkili okul ve okul geliştirme kuram uygulama ve araştırma. Altıncı Baskı. Ankara: Pegem A Publishing, 2013.

[3] A. Dijkstra, R. Daas, I. De la Motte, M. Ehren. Inspecting School Social Quality: Assessing and Improving School Effectiveness in the Social Domain. Journal of Social Science Education, Vol.16, NO.4, 75-84, DOI 10.4119/UNIBI/jsse-v16-i4-1640, 2017.

[4] B. Singh, M. Townsley." Making Sense of Georgia School Leader Evaluation: Climate, Engagement and the District Office," Georgia Educational Researcher, Vol. 17, NO.1, 2020. DOI: 10.20429/ger.2020.170104 Available at: https://digitalcommons.georgiasouthern.edu/gerjournal/vol1 7/iss $1 / 4$.

[5] C. Preston., E. J. Goldring, E. Guthrie, R. Ramsey, J. Huff. Conceptualizing Essential Components of Effective High Schools, Leadership and Policy in Schools, Vol. 16, No. 4, 525-562, 2017. DOI: 10.1080/15700763.2016.1205198.

[6] C. Uline, D. Miller, M. Tschannen-Moran. School effectiveness: The underlying dimensions. Educational Administration Quarterly, Vol. 34, 462-483,1998.

[7] E. Akay, A. Aypay. School Effectiveness and Comparison of the Effectiveness of Turkish State Secondary Schools According to Socioeconomic Status. The Turkish Online Journal of Educational Technology, Vol. 15, NO. 3, 453-467, 2016.

[8] European Commission. Education and Training Monitor 2019. 33 Council of the European Union (2019). Council recommendation of 22 May 2019 on High-Quality Early Childhood Education and Care Systems, OJ C 189, 5.6.2019.

[9] I. A. Negiş. Ethical Leadership and School Effectiveness: The Mediating Roles of Affective Commitment and Job Satisfaction. International Journal of Educational Leadership and Management, Vol. 8, NO. 1, 60 -87. doi: 10.17583/ijelm.2020.4114, 2020.

[10] İ. Baştepe. The School effectiveness perceptions of administrators, teacher and the eighth grade students in public normal and transported elementary schools, Unpublished $\mathrm{PhD}$ Thesis, Ankara University, Institute of Social Sciences, Ankara, 2002.

[11] J. Burušić., T. Babarović, M. Š. Velić. School Effectiveness: An Overview of Conceptual, Methodological and Empirical Foundations. In School Effectiveness and Educational Management. Springer International Publishing, 5-26, 2016.

[12] J. Gray. Investigating the Role of Collective Trust, Collective Efficacy, and Enabling School Structures on Overall School Effectiveness, NCPEA Education Leadership Review, Vol. 17, No. 1- May, 2016. ISSN: 1532-0723 (C) 2016 National Council of Professors of Educational Administration, 114-128,2016.
[13] J. Scheerens, B. Creemers. Conceptualizing school effectiveness. International Journal of Educational Research, Vol. 13, 691-706 ,1989.

[14] K. Songül, A. Müslim, S. Dönüș. The Effect of Teachers' Organizational Citizenship Behaviors and Stress Levels on School Effectiveness. European Journal of Education Studies, Vol. 5, NO. 4, 67-82,2018.

[15] K. Tosh, Ch. Doss. Perceptions of School Leadership: Implications for Principal Effectiveness. - RAND Corporation, 2019. https://www.rand.org/pubs/research_rep orts/RR2575z5-1.html

[16] K. Yang, J. Tu, T. Chen. Homoscedasticity: an overlooked critical assumption for linear regression, General Psychiatry, 2019; 32: e100148. doi:10.1136/ gpsych-2019-100148.

[17] M. Alanoğlu1, Z. Demirtaş. The Relationships between Organizational Learning Level, School Effectiveness and Organizational Citizenship Behavior, Journal of Education and Training Studies Vol. 4, No. 4; April 2016. ISSN 2324-805XE-ISSN 2324-8068, URL: http://jets.redfame.co $\mathrm{m}$

[18] M. Bottery. The challenges of educational leadership. Journal of Education for Teaching, Vol. 34, NO. 2, 157-163, 2014.

[19] M. Özgenel. An Organizational Factor Predicting School Effectiveness: School Climate, International Journal of Psychology and Educational Studies, Vol. 7, NO. 1, 38-50, 2020.

[20] M. Panigrahi,. School Effectiveness at Primary Level of Education in Relation to Classroom Teaching, International Journal of Instruction, Vol.7, No.2,. 51-64, 2014.

[21] O. Chiedozie, A. Victor, A.V. Akinfolarin. Principals' Application of Instructional Leadership Practices for Secondary School Effectiveness in OYO State, Journal of the Nigerian Academy of education - Jonaed, Vol 13, No. 1 MAY, 2017.

[22] OECD. Responsive School Systems - Connecting Facilities, Sectors and Programmes for Student Success. OECD Reviews of School Resources, 2018.

[23] OECD. PISA 2015 Results (Volume II): Policies and Practices for Successful Schools, 2016.

[24] R. Cakir, C. Kesme. Examination of Vocational High Schools' Effectiveness Levels in Terms of European Union Project Numbers, Universal Journal of Educational Research, Vol. 6, No. 10, 2341-2351, 2018. http://www.hrpub.org DOI: $10.13189 /$ ujer.2018.061033.3

[25] R. J. Botha. School effectiveness: conceptualizing divergent assessment approaches. South African Journal of Education, Vol. 30, 605- 620, 2010.

[26] R. Kempa, M. Ulorlo, I. Wenno. Effectiveness Leadership of Principal International Journal of Evaluation and Research in Education (IJERE) Vol.6, No.4, 306 -311, 2017. ISSN: $2252-8822$

[27] S. Al- Barami, S. Tanash. Effectiveness of Basic Public Schools in Sultanate of Oman as Perceived by Supervisors, Principals, and Teachers, Studies Educational Sciences, Vol. 35, No. 4 ,37-56, 2008. 
[28] S. Bishara. School Effectiveness and Student Achievement, International Journal of Contemporary Research and Review, Vol. 8, Issue. 2, 2017. No: SS 20171-20188 doi: http://dx.doi.org/10.15520/ijcrr/2017/8/02/123.

[29] W. Daher. Assessing students' perceptions of democratic practices in the mathematics classroom. Paper presented at the Eleventh Congress of the European Society for Research in Mathematics Education. Utrecht, The Netherlands, Februery 6-10, 2019.

[30] W.K. Hoy, C.G. Miskel. Educational Administration Theory, Research and Practice, Selahattin Turan (Editör). Ankara, Nobel Yayınları, 2012. 